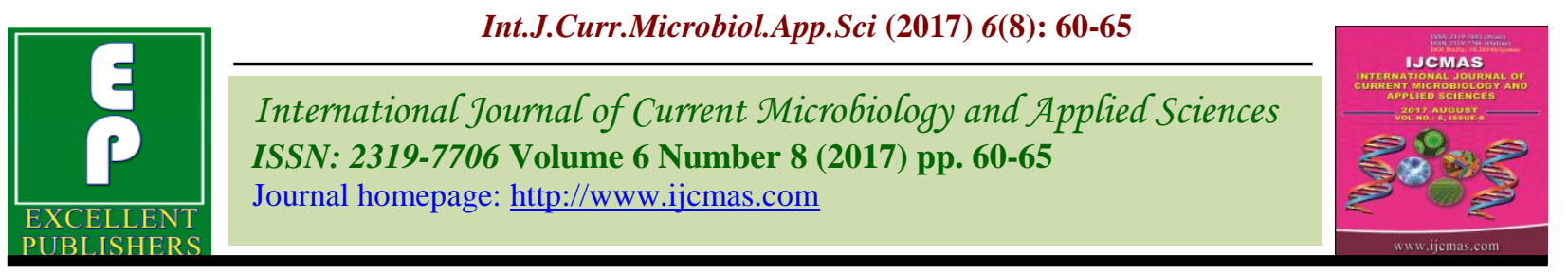

Original Research Article

https://doi.org/10.20546/ijcmas.2017.608.009

\title{
Effect of Integrated Nutrient Management on Growth, Flowering and Yield of African Marigold (Tagetes erecta L.)
}

\section{Mamta Kumawat $^{1}$, S.K. Khandelwal ${ }^{2}$, M.R. Choudhary ${ }^{3}$, P.K. Kumawat ${ }^{4}$, G. Sharma ${ }^{5}$ and Paru Panwar}

${ }^{1}$ Department of Agriculture, Bhhichawa, Kuchamancity, Nagaur, DOA, Govt. of Rajasthan, India

${ }^{2}$ Department of Horticulture, RARI, Durgapura (SKNAU, Jobner), Jaipur, India ${ }^{3}$ Department of Horticulture, S.K.N. College of Agriculture (SKNAU), Jobner, India ${ }^{4}$ Department of Agriculture, Kuchamancity, Nagaur, DOA, Govt. of Rajasthan, India ${ }^{5}$ Department of Agriculture, Lunkaransar, Bikaner, DOA, Govt. of Rajasthan, India ${ }^{6}$ Department of Agriculture, Rojari, Jhotwara, Jaipur, DOA, Govt. of Rajasthan, India *Corresponding author

\section{A B S T R A C T}

Keywords

African marigold, FYM, RDF,

Azotobacter, PSB, Growth, Flower and Yield

Article Info

Accepted:

04 June 2017

Available Online:

10 August 2017
The present investigation was carried out during rabi season 2009-10 to study the effect of integrated nutriment management on growth and yield of African marigold. The treatment consisted of four levels of FYM and inorganic fertilizers and four biofertilizers (control, Azotobacter, PSB and Azotobacter + PSB). Application of 75\% RDF + FYM @ $20 \mathrm{t} \mathrm{ha}^{-1}$ along with inoculation of seedlings with Azotobacter + PSB produced significantly higher plant height, number of primary branches plant ${ }^{-1}$, weight of flower, number of flowers plant ${ }^{-1}$, yield of flowers plot $^{-1}$ as well as $\mathrm{ha}^{-1}$. These parameters were statistically at par with the application of $50 \%$ RDF + FYM @ $20 \mathrm{t} \mathrm{ha}^{-1}$ along with inoculation of seedlings with Azotobacter+ PSB.

\section{Introduction}

African marigold (Tagetes erecta L.), is one of the most important hardy flower crops grown commercially in different parts of the world. Marigold gained popularity among gardens and flower dealers on account of its easy cultivation, wide adaptability of diverse soil and climatic conditions, habit of profuse flowering, short duration to produce marketable flowers, wide spectrum of attractive colours, shape and good keeping quality. In India, it is one of the most commonly grown loose flowers and extensively used on religious and social functions, in one form or another.

Application of $\mathrm{N}, \mathrm{P}$ and $\mathrm{K}$ through inorganic fertilizers can enhance the growth and yield to considerable. FYM provide a variety of plant nutrients and improve soil structure by providing binding effect to soil aggregates. It increases cation exchange capacity of the soil, water holding capacity and phosphate 
availability. The fertilizer use efficiency and microbial quality of the soil is also improved through FYM. It is rich in organic matter and can be supplemented with NPK fertilizers. Biofertilizers plays an important role in increasing availability of nutrients and productivity in sustainable manner. Azotobacter is free living bacteria which may add $25-30 \mathrm{~kg} \mathrm{~N} \mathrm{ha}^{-1}$ year $^{-1}$ in a field of nonlegume crop under favourable condition and also secrets some growth promoting substances. Inoculation of seeds with PSB culture increase nodulation, crop growth, nitrogenase activity, nutrient uptake and crop yield. Indiscriminate use of fertilizers and other agrochemicals has resulted in the depletion of beneficial micro-organism from the soil and has caused infertile and unproductive soil.

In this respect biofertilizers play multifaceted role by not only enriching the soil microorganism but also as nutrients, stabilizers, hormones and insulators (Bihari et al., 2009). The advantages of integrated nutrients management generally superior over use of each component separately. Integration of chemical fertilizers with organic manures and biofertilizers had maintained long term fertility and sustains higher productivity (Pillai et al., 1985). The lack of information on these aspects made as impetus to undertake the present study.

\section{Materials and Methods}

Field experiment was conducted at Experimental Farm, Department of Horticulture, S.K.N. College of Agriculture, Jobner during rabi season 2009-10. The treatment combinations comprised four levels of FYM and inorganic fertilizers (100\% RDF, FYM@20 $\mathrm{tha}^{-1}, 75 \%$ RDF and FYM @ $20 \mathrm{t}$ $\mathrm{ha}^{-1}$ and 50\% RDF and FYM @ $20 \mathrm{t} \mathrm{ha}^{-1}$ ) and four biofertilizers (control, Azotobacter, PSB and Azotobacter + PSB inoculation), thereby, made 16 treatment combinations, which were replicated thrice in the Factorial Randomized Block Design. Where, RDF represents recommended dose of N, P and K (120- 60$60 \mathrm{~kg} \mathrm{ha}^{-1}$ ) through inorganic fertilizers. Recommend dose of fertilizer (RDF) was applied as per treatment through DAP and urea as a basal dose. Five weeks old seedlings brought out from nursery bed and treated by dipping of roots into the prepared culture of biofertilizer as per treatments for 30 minutes and then transplanted into plots of $2.4 \mathrm{~m} \mathrm{x} 1.8$ $\mathrm{m}$ at spacing of $60 \times 45 \mathrm{~cm}$. The different growth and yield observations were recorded from five randomly selected plants from each plot. The other cultural operations were done as per recommendation and crop requirement.

\section{Results and Discussion}

\section{Growth attributes}

\section{Effect of integrated nutrient management}

The various combinations of integrated nutriment management significantly affect plant height and number of primary branches plant $^{-1}$. Maximum plant height $(64.58 \mathrm{~cm})$ and number of primary branches plant $^{-1}$ (13.51) were recorded with the application of $75 \%$ $\mathrm{RDF}+\mathrm{FYM} @ 20 \mathrm{t} \mathrm{ha}^{-1}$ which was significantly superior to rest of the treatments.

This might be due to the fact that nitrogen is a constituent of protein which helps in division and enlargement of cell, thereby, enhancing plant growth. The above results are in accordance with the finding of Chandha et al., (1999) and Acharya and Dashora (2004).

\section{Effect of biofertilizers}

Significantly higher values of plant height $(64.17 \mathrm{~cm})$ and number of primary branches plant $^{-1}$ (13.48) were recorded with inoculation of seedling with Azotobacter + PSB culture whereas, least plant height $(49.64 \mathrm{~cm})$ and number of primary branches plant ${ }^{-1}(10.37$ 
$\mathrm{cm})$ were recorded with no inoculation. This treatment (Azotobacter + PSB) increased the plant height and number of primary branches plant $^{-1}$ by 10.44 and 4.39 per cent over no inoculation, respectively. This could be explained by the activities of the inoculants viz. nitrogen fixation, release of $\mathrm{Pi}$ from insoluble phosphate, production of phytohormones etc. with simultaneous uptake of nutrients. Increase cell elongation and cell multiplication due to enhanced nutrient uptake following inoculation of Azotobacter and PSB might have caused plant height (Preethi et al., 1999).

\section{Interaction effect}

It was observed that integrated nutrient management along with biofertilizers leaves every possibility of interactions among their different levels thereby reflecting effect on the vegetative growth of plants. Application of $75 \% \mathrm{RDF}+\mathrm{FYM} @ 20 \mathrm{t} \mathrm{ha}^{-1}$ along with inoculation of seedlings with Azotobacter + PSB culture recorded maximum plant height $(68.74 \mathrm{~cm})$ and number of primary branches plant $^{-1}$ (14.44), while this treatment was statistically at par with 50\% RDF + FYM @ $20 \mathrm{t} \mathrm{ha}^{-1}$ along with inoculation of seedlings with Azotobacter + PSB $\left(\mathrm{F}_{4} \mathrm{~B}_{3}\right)$ and $75 \%$ RDF + FYM @ $20 \mathrm{t} \mathrm{ha}^{-1}$ along with inoculation of seedlings with Azotobacter $\left(\mathrm{F}_{3} \mathrm{~B}_{1}\right)$ (Table 2$)$. The favourable influence of applied RDF and FYM along with biofertilizers on these characters may be ascribed in the light of balanced nutrition. It is an established fact that balanced nutrition cause great expression in term of crop growth. Striking influence of RDF and FYM along with Azotobacter + PSB probably increased availability of nutrients specially nitrogen and phosphorus in the soil and augmented to increase plant height and number of primary branches. These results are also experimentally substantiated with the findings of earlier workers Singh (2006) in rose and Bhalla et al., (2007) in carnation.

\section{Floral attributes}

\section{Effect of FYM and inorganic fertilizer}

Data presented in table 1 showed that application of different integrated nutrient sources had significant effect on average weight of flower and number of flowers plant ${ }^{-}$ 1 . Maximum average weight of flower $(8.24 \mathrm{~g})$ and number of flowers plant ${ }^{-1}$ (64.33) were observed under the treatment $75 \% \mathrm{RDF}+$ FYM @ 20t ha ${ }^{-1}\left(\mathrm{~F}_{3}\right)$ which was significantly superior to other treatments. 75\% RDF + FYM @ $20 \mathrm{t} \mathrm{ha}^{-1}$ registered an increase average weight of flower and number of flowers plant ${ }^{-1}$ to the tune of 13.49 per cent and 13.53 per cent over application of $100 \%$ RDF. It could also be attributed due to fact that after proper decomposition and mineralization, the organic manure supplied available nutrient directly to the plant and also had solublizing effect on fixed form of nutrients in soil and thus improvement in physical and biological properties of the soil (Sinha et al., 1981).

\section{Effect of biofertilizers}

Similarly, average weight of flower and number of flowers plant ${ }^{-1}$ were significantly influenced with the inoculation of seedling with biofertilizers. Maximum weight of flower $(8.22 \mathrm{~g})$ and number of flowers plant ${ }^{-1}$ (67.17) were recorded with inoculation with Azotobacter + PSB $\left(\mathrm{B}_{3}\right)$. This treatment (Azotobacter + PSB) registered an enhancement of average weight of flower to the tune of 36.45 per cent and number of flowers plant ${ }^{-1}$ to the extent of 30.24 per cent over no inoculation. The earliness of bud initiation in biofertilizer inoculated plants may be ascribed to easy uptake of nutrients and simultaneous transport of growth promoting substances like cytokinin to the axillary buds resulting in breakage of apical dominance. Ultimately this has resulted in a 
better sink for faster mobilization of photosynthates and early transformation of plant parts from vegetative to reproductive phase. The results are in line with findings in Marigold (Chandrikapure et al., 1999) and Limonium (Gayathri et al., 2004).

Table.1 Effect of FYM, inorganic fertilizers and biofertilizers on different growth and Yield attributes in African marigold

\begin{tabular}{|c|c|c|c|c|c|c|}
\hline Treatments & $\begin{array}{l}\text { Plant } \\
\text { height } \\
\text { (cm) }\end{array}$ & $\begin{array}{l}\text { No. of } \\
\text { primary } \\
\text { branches }\end{array}$ & $\begin{array}{l}\text { Weight of } \\
\text { flower }(\mathrm{g})\end{array}$ & $\begin{array}{l}\text { Number of } \\
\text { flowers plant }^{-1}\end{array}$ & $\begin{array}{l}\text { Yield of } \\
\text { flowers }(k g \\
\left.\text { plot }^{-1}\right)\end{array}$ & $\begin{array}{l}\text { Yield of } \\
\text { flowers }\left(q \mathrm{ha}^{-1}\right)\end{array}$ \\
\hline \multicolumn{7}{|c|}{ A. FYM and inorganic fertilizers } \\
\hline$F_{1}(100 \%$ RDF $)$ & 56.16 & 11.90 & 7.26 & 56.66 & 7.12 & 164.67 \\
\hline$F_{2}\left(\right.$ FYM @ $\left.20 \mathrm{tha}^{-1}\right)$ & 49.08 & 10.29 & 6.26 & 49.92 & 6.14 & 142.12 \\
\hline $\begin{array}{l}F_{3}(75 \% \text { RDF and FYM } \\
\left.@ 20 \mathrm{tha}^{-1}\right)\end{array}$ & 64.58 & 13.51 & 8.24 & 64.33 & 8.16 & 188.69 \\
\hline $\begin{array}{l}\text { F }_{4}(50 \% \text { RDF and FYM } \\
\left.\text { @ 20 t ha }{ }^{-1}\right) \\
\end{array}$ & 61.37 & 12.84 & 7.83 & 61.12 & 7.76 & 179.58 \\
\hline SEm+ & 0.90 & 0.18 & 0.11 & 0.88 & 0.11 & 2.58 \\
\hline CD at $5 \%$ & 2.61 & 0.51 & 0.33 & 2.55 & 0.32 & 7.45 \\
\hline \multicolumn{7}{|l|}{ B. Bio-fertilizers } \\
\hline $\mathbf{B}_{0}$ (No inoculation) & 49.94 & 10.37 & 6.31 & 49.27 & 6.23 & 144.06 \\
\hline $\mathbf{B}_{1}($ Azotobacter $)$ & 12.75 & 7.78 & 60.73 & 7.67 & 7.67 & 177.58 \\
\hline $\mathbf{B}_{2}(\mathbf{P S B})$ & 56.60 & 11.94 & 7.28 & 56.85 & 7.17 & 165.89 \\
\hline $\begin{array}{l}\text { B } \\
\text { inoculation) }\end{array}$ & 64.17 & 13.48 & 8.22 & 64.17 & 8.11 & 187.53 \\
\hline SEm \pm & 0.90 & 0.18 & 0.11 & 0.88 & 0.11 & 2.58 \\
\hline CD at $5 \%$ & 2.61 & 0.51 & $\mathbf{0 . 3 3}$ & 2.55 & 0.32 & 7.45 \\
\hline
\end{tabular}

Table.2 Interactive effect of FYM, inorganic fertilizers and biofertilizers on different growth and Yield attributes in African marigold

\begin{tabular}{|l|c|c|c|c|c|c|}
\hline Treatments & $\begin{array}{c}\text { Plant height } \\
(\mathbf{c m})\end{array}$ & $\begin{array}{c}\text { No. of } \\
\text { primary } \\
\text { branches }\end{array}$ & $\begin{array}{c}\text { Weight of } \\
\text { flower (g) }\end{array}$ & $\begin{array}{c}\text { Number of } \\
\text { flowers per } \\
\text { plant }\end{array}$ & $\begin{array}{c}\text { Yield of } \\
\text { flowers per } \\
\text { plot (kg) }\end{array}$ & $\begin{array}{c}\text { Yield of } \\
\text { flowers per } \\
\text { hectare (q) }\end{array}$ \\
\hline $\mathbf{F}_{\mathbf{1}} \mathbf{B}_{\mathbf{0}}$ & 49.64 & 10.42 & 6.36 & 49.64 & 6.23 & 144.16 \\
\hline $\mathbf{F}_{\mathbf{1}} \mathbf{B}_{\mathbf{1}}$ & 58.10 & 12.41 & 7.57 & 59.10 & 7.45 & 172.36 \\
\hline $\mathbf{F}_{\mathbf{1}} \mathbf{B}_{\mathbf{2}}$ & 53.94 & 11.54 & 7.04 & 54.94 & 6.87 & 159.01 \\
\hline $\mathbf{F}_{\mathbf{1}} \mathbf{B}_{\mathbf{3}}$ & 62.96 & 13.22 & 8.07 & 62.96 & 7.92 & 183.15 \\
\hline $\mathbf{F}_{\mathbf{2}} \mathbf{B}_{\mathbf{0}}$ & 35.24 & 7.35 & 4.41 & 34.57 & 4.34 & 100.42 \\
\hline $\mathbf{F}_{\mathbf{2}} \mathbf{B}_{\mathbf{1}}$ & 53.80 & 11.30 & 6.89 & 53.80 & 6.75 & 156.26 \\
\hline $\mathbf{F}_{\mathbf{2}} \mathbf{B}_{\mathbf{2}}$ & 49.53 & 10.40 & 6.34 & 49.53 & 6.21 & 143.67 \\
\hline $\mathbf{F}_{\mathbf{2}} \mathbf{B}_{\mathbf{3}}$ & 57.76 & 12.13 & 7.40 & 57.76 & 7.27 & 168.11 \\
\hline $\mathbf{F}_{\mathbf{3}} \mathbf{B}_{\mathbf{0}}$ & 59.56 & 12.30 & 7.50 & 58.56 & 7.42 & 171.72 \\
\hline $\mathbf{F}_{\mathbf{3}} \mathbf{B}_{\mathbf{1}}$ & 66.54 & 13.97 & 8.52 & 66.54 & 8.44 & 195.37 \\
\hline $\mathbf{F}_{\mathbf{3}} \mathbf{B}_{\mathbf{2}}$ & 63.49 & 13.33 & 8.13 & 63.49 & 8.06 & 186.57 \\
\hline $\mathbf{F}_{\mathbf{3}} \mathbf{B}_{\mathbf{3}}$ & 68.74 & 14.44 & 8.81 & 68.74 & 8.72 & 201.11 \\
\hline $\mathbf{F}_{\mathbf{4}} \mathbf{B}_{\mathbf{0}}$ & 55.32 & 11.41 & 6.96 & 54.32 & 6.91 & 159.94 \\
\hline $\mathbf{F}_{\mathbf{4}} \mathbf{B}_{\mathbf{1}}$ & 63.49 & 13.33 & 8.13 & 63.49 & 8.05 & 186.34 \\
\hline $\mathbf{F}_{\mathbf{4}} \mathbf{B}_{\mathbf{2}}$ & 59.44 & 12.48 & 7.61 & 59.44 & 7.53 & 174.29 \\
\hline $\mathbf{F}_{\mathbf{4}} \mathbf{B}_{\mathbf{3}}$ & 67.23 & 14.12 & 8.61 & 67.23 & 8.53 & 197.74 \\
\hline $\mathbf{S E m +}$ & $\mathbf{1 . 8 1}$ & $\mathbf{0 . 3 5}$ & $\mathbf{0 . 2 3}$ & $\mathbf{1 . 7 6}$ & $\mathbf{0 . 2 2}$ & $\mathbf{5 . 1 6}$ \\
\hline $\mathbf{C D}_{\mathbf{a t}} \mathbf{5} \%$ & $\mathbf{5 . 2 3}$ & $\mathbf{1 . 0 2}$ & $\mathbf{0 . 6 6}$ & $\mathbf{5 . 1 0}$ & $\mathbf{0 . 6 4}$ & $\mathbf{1 4 . 9 0}$ \\
\hline
\end{tabular}




\section{Interaction effect}

The application of 75\% RDF + FYM @ $20 \mathrm{t}$ $\mathrm{ha}^{-1}+$ inoculation of seedlings with Azotobacter + PSB culture significantly enhanced floral characters.

This treatment combination $\left(\mathrm{F}_{3} \mathrm{~B}_{3}\right)$ was found best for number of flowers plant ${ }^{-1}$ (68.74) and weight of flower $(8.81 \mathrm{~g})$, it was statistically at par with 50\% RDF + FYM @ $20 \mathrm{t} \mathrm{ha}^{-1}$ along with inoculation of seedlings with Azotobacter + PSB $\left(\mathrm{F}_{4} \mathrm{~B}_{3}\right)$ and $75 \% \mathrm{RDF}+$ FYM@20 t ha ${ }^{-1}$ along with inoculation of seedlings with Azotobacter $\left(\mathrm{F}_{3} \mathrm{~B}_{1}\right)$ (Table 2).

The enhancement in flowering attributes i.e. number of flowers and weight of flower was possibly due to better nutrients uptake, photosynthesis, source to sink relationship, besides excellent physiological and biochemical activities due to presence of FYM, chemical fertilizers, Azotobacter + PSB.

Similar, effect was reported by Swaminathan et al., (1999) in tuberose and Gayithri et al., (2004) in statice.

\section{Yield attributes}

\section{Effect of FYM and inorganic fertilizer}

Application of FYM along with inorganic fertilizers significantly enhanced the yield characters and yield of marigold. Maximum yield of flower $\left(8.16 \mathrm{~kg} \mathrm{plot}^{-1}\right.$ and $188.69 \mathrm{q}$ $\mathrm{ha}^{-1}$ ) were recorded with application of $75 \%$ RDF + FYM @20 t ha ${ }^{-1}$ which was significantly higher over rest of the treatments.

Application of 75\% RDF + FYM @ $20 \mathrm{tha}^{-1}$ increased the yield of flowers by 14.60 per cent plot $^{-1}$ and 14.58 per cent ha ${ }^{-1}$ over $100 \%$ $\mathrm{RDF}$. The increase in yield with increasing levels of nitrogen application (could be attributed to the increase in vegetative growth). These results are in conformity with Agrawal et al., (2002) who reported significantly higher yield with higher levels of nitrogen application in African marigold.

The similar effects were given by Singh (2005) in Rose might due to additional supply of plant nutrients at proper time as well as sources of fertilizer application.

\section{Effect of biofertilizers}

Yield of flowers $\operatorname{plot}^{-1}$ and $\mathrm{ha}^{-1}$ were significantly increased with inoculation of seedling with biofertilizers as compared to no inoculation. Inoculation of seedling with Azotobacter + PSB exerted maximum yield of flowers $\left(8.11 \mathrm{~kg} \mathrm{plot}^{-1}\right.$ and $\left.187.53 \mathrm{q} \mathrm{ha}^{-1}\right)$. Treatment, inoculation of seedling with Azotobacter + PSB culture increased the yield of flowers plot $^{-1} 30.17$ per cent and yield of flower $\mathrm{ha}^{-1}$ by 30.17 per cent over no inoculation.

\section{Interaction effect}

Yield of flowers $\left(8.53 \mathrm{~kg} \mathrm{plot}^{-1}\right.$ and $197.74 \mathrm{q}$ $\mathrm{ha}^{-1}$ ) were exhibited maximum with application of 50\% RDF + FYM @ $20 \mathrm{t} \mathrm{ha}^{-1}$ along with inoculation of seedling with Azotobacter + PSB. The increase in flowers yield might be due to the possible role of organic, inorganic fertilizers and Azotobacter through atmospheric nitrogen fixation, better root proliferation, uptake of nutrients and water, higher photosynthetic activity and enhanced food accumulation which might have resulted in better plant growth and subsequently higher yield. Besides this the increased yield might be attributed to the increased availability of phosphorus through PSB. The present result was also similar to the findings of Chandrikapure et al., 1999 and Gayithri et al., 2004. 


\section{Acknowledgement}

The authors express their sincere thanks to Sh. Prabhakar Singh (Retd. Associate Professor and Head, Department of Horticulture, S.K.N. COA, Jobner) for his constructive suggestions and guidance during this study. Financial assistance in the form of Departmental merit scholarship from S.K.R.A.U., Bikaner is duly acknowledged.

\section{References}

Acharya, M. M. and Dashora, L. K., 2004. Response of graded levels of Nitrogen and Phosphorus on vegetative growth and flowering in African marigold (Tegets erecta L.). Journal of Ornamental Horticulture, 7 (2):179-183.

Agarwal, S., Agarwal, N., Dixit, A. and Yadav, R. N., 2002. Effect of $\mathrm{N}$ and $\mathrm{K}_{2} \mathrm{O}$ on African marigold in Chhattisgarh region. Journal of Ornamental Horticulture, 5 (1):86.

Bhalla, R., Kumar, M.H. and Jain, R., 2007. Effect of organic manures and biofertilizers on growth and flowering in carnation. Journal of Ornamental Horticulture, 10 (4): 229-234.

Bihari, M., Narayan, S. and Singh, A.K., 2009. Effect of pruning levels and bio-fertilizers on production of Rose cut flowers. Journal of Ornamental Horticulture, 12(1): 48-53.

Chandha, A. P.S., Rathore, S.V.S. And Ganesh, R. K., 1999. Influence of Nitrogen and Phosphorus and ascorbic acid on yield and flowering of African marigold cv. Double giant. Journal of South Indian Horticulture, 47 (1-6): 342-344.

Chandrikapure, K.R., Sadawrte, K.T., Panchbhait, D.M. and Shelke, B.D., 1999.
Effect of bioinoculants and graded dose of $\mathrm{N}_{2}$ on growth and flower yield of marigold. Orissa Journal of Horticulture, 27 (2): 31-34.

Gayithri, H.N., Jayaprasad, K.V. and Narayanaswamy, P., 2004. Response of biofertilizers and their combined application with different levels of organic fertilizers in statice. Journal of Ornamental Horticulture, 70: 70-74.

Pillail, K.G., Devi, S.I., and Setty, T.K.D., 1985. Research achievement of All India Co-ordinated Agro-nomical Research Project Fertilizer News, 30: 26-34.

Preethi, T. L., Pappiah, C. M. and Anbu, S., 1999. Studies on the effect of Azospirillum sp., Nitrogen and Ascorbic acid on growth and flowering of Edward Rose (Rosa bourbonians). Journal of South Indian Horticulture, 47 (1-6): 106110.

Sinha, N., Prasad, P. and Gosh, A. B., 1981. Effect of continuous use of fertilizers on yield and nutrient uptake in wheat, soyabean, potato cropping system. Journal of Indian society of soil science, 29: 537-542.

Singh, A. K., 2005. Response of rose plant growth and flowering to Nitrogen, Azotobacter and FYM. Journal of Ornamental Horticulture, 8 (4): 296-298.

Singh, A.K., 2006. Effect of FYM, Azotobacter and $\mathrm{N}_{2}$ on leaf nutrient content composition, growth, flowering and yield in rose. Indian Journal of Horticulture, 63 (3): 62-65.

Swaminathan, V., Ramaswamy, N. and Pillai, O.A.A., 1999. Effect of Azospirillium phosphobacteria and inorganic nutrients on growth and yield of tuberose. South Indian Horticulture, 47 (1-6): 331-334.

\section{How to cite this article:}

Mamta Kumawat, S.K. Khandelwal, M.R. Choudhary, P.K. Kumawat, G. Sharma and Paru Panwar. 2017. Effect of Integrated Nutrient Management on Growth, Flowering and Yield of African Marigold (Tagetes erecta L.). Int.J.Curr.Microbiol.App.Sci. 6(8): 60-65. doi: https://doi.org/10.20546/ijcmas.2017.608.009 